\title{
Indication of migrated hydrocarbons in Tertiary volcanic rocks from western Nûgssuaq, central West Greenland
}

\author{
A. K. Pedersen
}

During the field season of 1985 the author briefly visited Marrait kitdlit at the southern part of the entrance to the Itivdle valley on Nûgssuaq (fig. 1). This paper briefly describes the occurrence of possibly migrated organic material in a vein in Tertiary basalt and presents it in a regional context.

\section{Regional geology}

The Marrait kitdlit area has been mapped in some detail (Henderson, 1975) and is well known for its few metres thick calcareous fossiliferous conglomerates (Hansen, 1970; Rosenkrantz, 1970; Jürgensen \& Mikkelsen, 1974), and for its hydrothermal veins (KarupMøller, 1969; Binzer \& Karup-Møller, 1974). A sequence of hyaloclastites and minor fossiliferous conglomerates is overlain by picritic and olivine-poor basaltic lava flows, all belonging to the early Tertiary Vaigat Formation. Later faulting has cut the volcanic pile into blocks which are downthrown by about 0.5 to $1 \mathrm{~km}$ compared to a stable plateau $5 \mathrm{~km}$ to the east. Scattered exposures of Cretaceous to early Tertiary marine mudstone with intercalated sandstone occur in the Itivdle valley and represent the pre-volcanic substratum (Henderson et al., 1976). West of the Itivdle valley a sequence of basalts at least $3 \mathrm{~km}$ thick from the Maligât Formation, which overlies the Vaigat Formation, is exposed (Hald, 1976) suggesting that the investigated locality at Marrait kitdlit was once covered by several kilometres of volcanic rocks. A major NE-SW striking fault zone extends from the southern tip of Hareøen through the Itivdle valley to Umanak Fjord over a distance of at least $60 \mathrm{~km}$ (fig. 1). Associated with this fault zone is the largest known palaeo-hydrothermal high-temperature area in the Tertiary volcanic province of West Greenland. The high-temperature hydrothermal zone is observed on the southern part of Hareøen as local fossil hot spring areas where basaltic lavas and tuffs are altered to crumbling white and grey masses, and in Itivdle as areas of hydrothermally metamorphosed lavas and hyaloclastites which may locally contain epidote. The degree of metamorphism in these areas exceeds by far the regional non-penetrative low zeolite facies metamorphism which characterizes the volcanic lithologies elsewhere in the Disko-Nûgssuaq region.

\section{Hydrothermal vein}

A hydrothermal vein is exposed over a distance of a few metres in the Marrait kitdlit area on the southern flank of a NW-SE trending ridge just west of Tufdalen about $50 \mathrm{~m}$ southwest of the main fossiliferous conglomerate at Tufdalen (loc. 2 in Binzer \& Karup-Møller, 1974). The vein, which cuts through olivine-poor subaerial basalt lava flows, is about $10 \mathrm{~cm}$ thick and consists of aggregates of centimetre-sized carbonate crystals. In the inner part of the vein are cavities which are partly filled by a loose black granular powder (fig. 2). The 


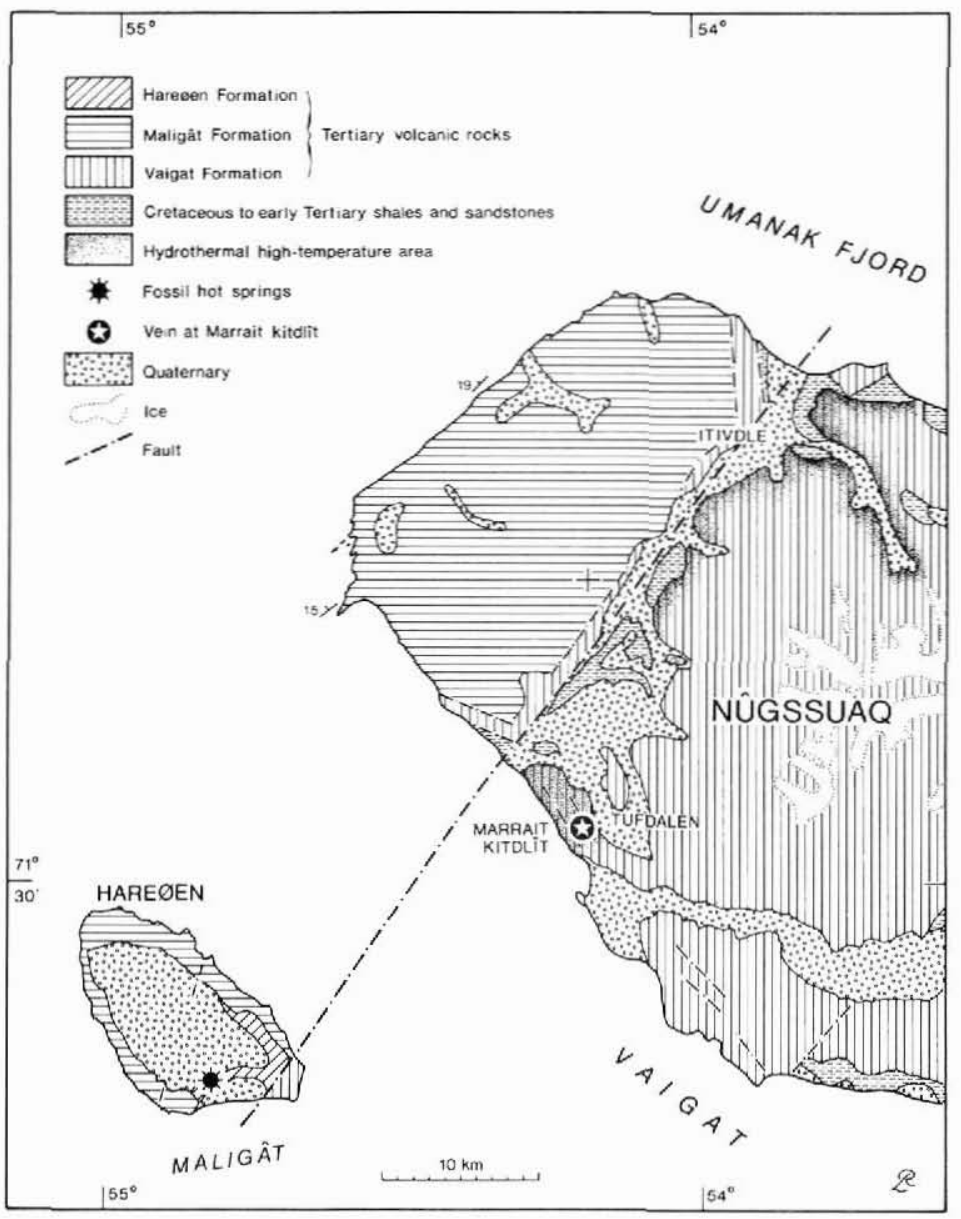

Fig. 1. The western Nûgssuaq and Hareøen region with the prominent Itivdle-Hareøen fault system, which is thought to be a part of the major NE-SW trending transform fault system in Baffin Bay formed at anomaly 20 to 24 time (e.g. Menzies, 1982). Hydrothermal high-temperature areas in the Itivdle valley and the fossil hot springs at Hareøen are shown.

'powder' consists of from $<0.2$ to $1 \mathrm{~mm}$ grains of clay coated by a black substance which also coats parts of the carbonate crystals of the cavity walls.

A cursory examination of cleavage fragments of the carbonate has revealed the presence of aqueous liquid-vapour inclusions (degree of filling about 0.95 ) with salinities around two equivalent weight \% $\mathrm{NaCl}$. No hydrocarbon-bearing inclusions were found (J. KonnerupMadsen, personal communication, 1985).

A sample of the clay granules (GGU 279075) has been analyzed for total carbon (TC) and 'total organic carbon' (TOC) and a Rock Eval analysis has been carried out by the source rock laboratory of DGU and GGU. The sample contains $1.30 \mathrm{wt} \% \mathrm{TC}$ and $1.18 \mathrm{wt} . \%$ TOC and the hydrocarbons are completely degraded, probably by thermal alteration. The 'or- 


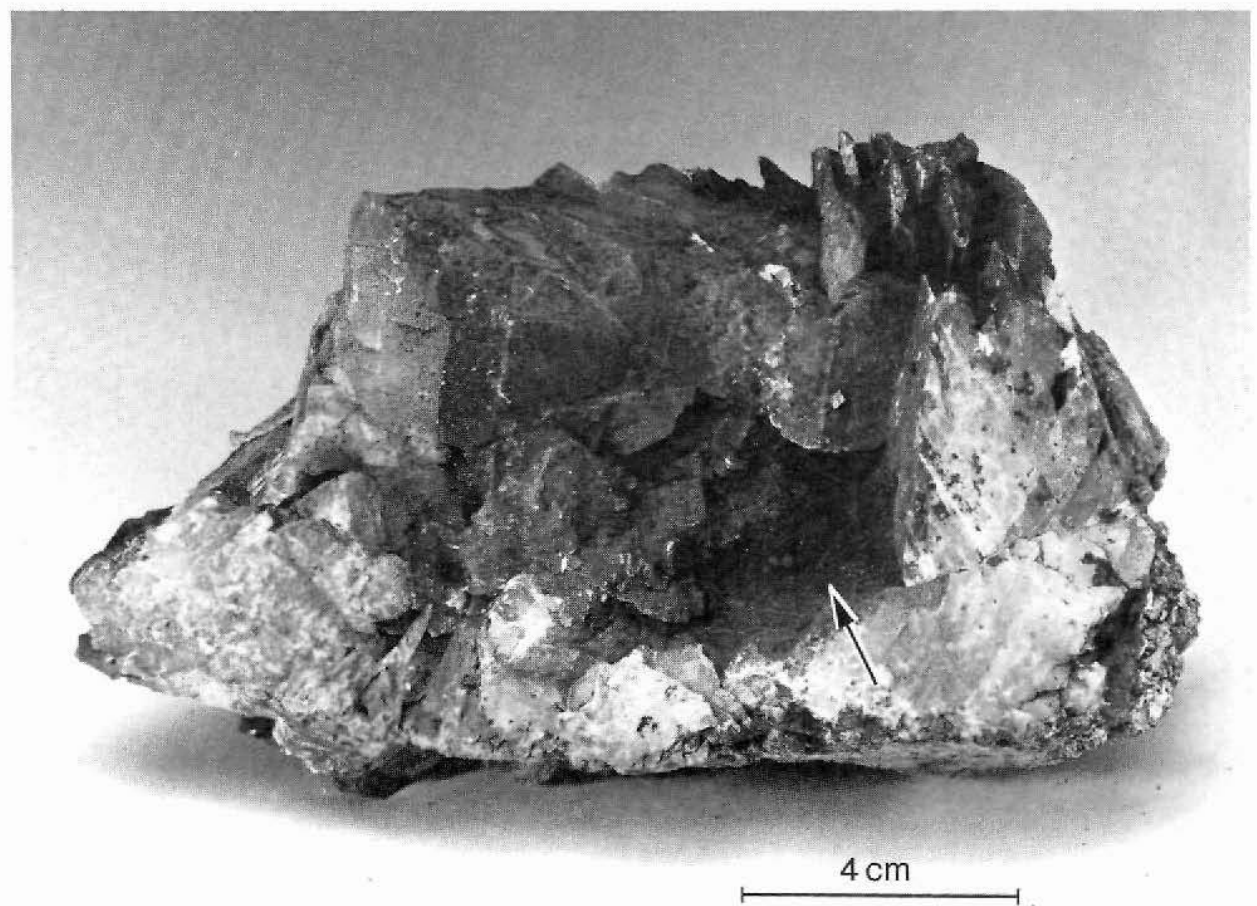

Fig. 2. Carbonate vein with cavities partly filled by clay substance coated with black degraded organic material, sample GGU 279076 from Marrait kitdlit. Sample 279075 was taken from the cavity shown by the white arrow. Photo: O.B. Berthelsen.

ganic carbon' presumably occurs as the thin black coating which must have precipitated from a fluid phase.

\section{Implications}

The oil and gas potential of the Cretaceous to Early Tertiary shales in West Greenland has been assessed by Henderson (1969), Schiener \& Leythaeuser (1978), Perregaard (1979) and Henderson et al. (1981). Generally, the sediments are characterized by thermally immature organic matter. Exceptions are contact zones to Tertiary igneous intrusive bodies and the Itivdle fault zone. Perregaard (1979) noted the presence of elevated maturation levels in oil source rocks in Upper Cretaceous/Paleocene shales in the Itivdle area.

The present example shows that hydrocarbons have migrated vertically at least $500 \mathrm{~m}$ upwards into Vaigat Formation volcanic rocks within the Itivdle-Hareøen fault zone. A former high-temperature hydrothermal zone extends for at least $8 \mathrm{~km}$ across the fault system and it is likely that at least several hundred square kilometres (and probably much more) within the Itivdle-Hareøen fault system have been affected by the hot hydrothermal solutions. Consequently, organic matter in a considerable volume of shale, both onshore and offshore in the area, could have generated hydrocarbons. 
Acknowledgements. The author wishes to acknowledge field support from the Arctic Station, Godhavn, and from Greenex A/S. The source rock laboratory of DGU and GGU provided analytical data. The work was supported by the Danish Natural Science Research Council.

\section{References}

Binzer, K. \& Karup-Møller, S. 1974: Ferri-sepiolite in hydrothermal calcite-quartz-chalcedony veins on Nûgssuaq in West Greenland. Bull. Grønlands geol. Unders. 114, (also Meddr Grønland 201(5)), 16 pp.

Hald, N. 1976: Early Tertiary flood basalts from Hareøen and western Nûgssuaq, West Greenland. Bull. Grønlands geol. Unders. 120, $36 \mathrm{pp}$.

Hansen, H. J. 1970: Danian foraminifera from Nûgssuaq, West Greenland with special reference to species occurring in Denmark. Bull. Grønlands geol. Unders. 93, (also Meddr Grønland 193(2)), 132 pp.

Henderson, G. 1969: Oil and gas prospects in the Cretaceous - Tertiary basin of West Greenland. Rapp. Grønlands geol. Unders. 22, $63 \mathrm{pp}$.

Henderson, G. 1975: Stratigraphy and structure of the Tertiary volcanic rocks of the Marrait kitdlit area, Nûgssuaq. Rapp. Grønlands geol. Unders. 69, 11-16.

Henderson, G., Rosenkrantz, A. \& Schiener, E. J. 1976: Cretaceous - Tertiary sedimentary rocks of West Greenland. In Escher, A. \& Watt, W. S. (edit.) Geology of Greenland, 340-362. Copenhagen: Geol. Surv. Greenland.

Henderson, G., Schiener, E. J., Risum, J. B., Croxton, C. A. \& Andersen, B. B. 1981: The West Greenland basin. Mem. Can. Soc. Petrol. Geol. 7, 399-428.

Jürgensen, T. \& Mikkelsen, N. 1974: Coccoliths from volcanic sediments (Danian) in Nûgssuaq, West Greenland. Bull. geol. Soc. Denmark 23, 225-230.

Karup-Møller, S. 1969: Xonotlite-, pectolite- and natrolite-bearing fracture veins in volcanic rocks from Nûgssuaq, West Greenland. Bull. Grønlands geol. Unders. 80 (also Meddr Grønland 186,2), 19 pp.

Menzies, A. W. 1982: Crustal history and basin development of Baffin Bay. In Dawes, P. R. \& Kerr, J. W. (edit.) Nares Strait and the drift of Greenland: a conflict in plate tectonics. Meddr Grønland, Geosci. 8, 295-312.

Perregaard, J. 1979: Organic geochemistry of sedimentary organic matter from Greenland: a petroleum source rock evaluation. Unpublished. Geol. Surv. Greenland. Open File Report, 81 pp. \& appendix.

Rosenkrantz, A. 1970: Marine upper Cretaceous and lowermost Tertiary deposits in West Greenland. Meddr dansk geol. Foren. 19, 406-453.

Schiener, E. J. \& Leythaeuser, D. 1978: Petroleum potential off West Greenland. Oil Gas J. 76(40), 223-234. 